\title{
Application of PCR-based methods for rapid detection of corn ingredients in processed foods
}

\author{
Inga Gabriadze ${ }^{1}$, Tamara Kutateladze ${ }^{1}$, Boris Vishnepolsky ${ }^{1}$, Marina Karseladze ${ }^{1}$, \\ Nelly Datukishvili ${ }^{1,2, *}$
}

${ }^{1}$ I. Beritashvili Center of Experimental Biomedicine, Tbilisi, Georgia

${ }^{2}$ Faculty of Arts and Sciences, Ilia State University, Tbilisi, Georgia

\section{Email address:}

neli_datukishvili@iliauni.edu.ge (N. Datukishvili)

\section{To cite this article:}

Inga Gabriadze, Tamara Kutateladze, Boris Vishnepolsky, Marina Karseladze, Nelly Datukishvili. Application of PCR-Based Methods for Rapid Detection of Corn Ingredients in Processed Foods. International Journal of Nutrition and Food Sciences.

Vol. 3, No. 3, 2014, pp. 199-202. doi: 10.11648/j.jinfs.20140303.21

\begin{abstract}
A rapid and accurate detection of corn (Zea mays L.) ingredients in processed foods is important for food safety and quality assurance. This study aimed to develop PCR-based approach for fast screening of the corn in foodstuffs. To this purpose a new PCR-based DNA marker specific to the corn zein gene was developed, three uniplex PCR methods and one triplex PCR system targeting invertase and zein genes were compared. Different corn-derived foodstuffs such as: flour, chips, flakes and snacks were investigated. Analysis of PCR products by agarose gel electrophoresis demonstrated that multiplex PCR method represents the most reliable and rapid tool for identification of corn ingredients in highly processed foods.
\end{abstract}

Keywords: Corn, Processed Foods, Genomic DNA Extraction, PCR Analysis

\section{Introduction}

Corn (Zea mays L.) is one of the world's leading food crops. It is widely utilized as raw material, additive and ingredient in food and feed production. Corn is found in a wide variety of packaged foods, such as cereals, candies, jams, syrups, sauces, snack foods, canned fruits, prepared meats and beverages. Though not considered a common food allergen corn allergy is increasingly being discussed between doctors across the world [1-2]. Treatment for corn allergy includes strict avoidance of corn ingredients. Knowledge about the presence of allergens in foods is important to avoid health problems. In addition, corn is one of the four most important genetically modified (GM) crops [3-4]. The reliable identification of corn is required for GM food labeling and monitoring to meet the consumers' demand for freedom of choice. Accurate information on the presence of corn in processed foods is important for food authenticity, quality and safety assessment.

Different molecular methods were developed for identification of corn (maize) [5]. DNA-based polymerase chain reaction (PCR) is recognized as the most effective technique for analysis of foodstuffs as DNA is the most stable molecule during food processing and production. Several PCR-based markers, such as: PCR products of invertase gene [6-9], zea mays $10 \mathrm{KDa}$ zein gene [10-11] and starch synthase IIb gene [12] were developed for detection of corn. However fast and reliable tracking of the corn ingredients and additives is a great challenge because of the degradation of proteins and DNA through food processing.

In this study, a new PCR-based DNA marker specific for corn zein gene was developed, in addition three uniplex PCR and one multiplex PCR methods were compared for effective detection of corn in processed foods.

\section{Materials and Methods}

\subsection{Food Material}

The locally produced corn (Zea mays) flour and snacks as well as the imported corn chips and flakes were purchased in a supermarket in Tbilisi (Georgia). The flour was subjected directly to DNA extraction, while chips, flakes and snacks were frozen in liquid nitrogen and ground by mortar and pestle to obtain a fine powder.

\subsection{DNA Extraction}

The genomic DNA was extracted from $100 \mathrm{mg}$ of each sample by cetyltrimethyl ammonium bromide 
(CTAB)-based method modified in our laboratory as follows: sample was mixed with $300 \mu \mathrm{l}$ sterile deionised water, 500 $\mu \mathrm{l}$ of CTAB buffer (20 g CTAB/1, 1.4M NaCl, $0.1 \mathrm{M}$ Tris-HCl, $20 \mathrm{mM}$ EDTA $)$ and $20 \mu \mathrm{l}$ proteinase $\mathrm{K}(20 \mathrm{mg} / \mathrm{ml})$. After the incubation at $65^{\circ} \mathrm{C}$ for $1.5 \mathrm{~h}, 20 \mu \mathrm{l}$ RNase A (10 $\mathrm{mg} / \mathrm{ml}$ ) was added. The mixture was incubated at $65^{\circ} \mathrm{C}$ for $10 \mathrm{~min}$. After the centrifugation at $16,000 \mathrm{~g}$ for $10 \mathrm{~min}$, the supernatant was extracted with $500 \mu$ l chloroform twice. The upper phase was transferred to a new tube, mixed with double volume of CTAB precipitation solution $(5 \mathrm{~g} / \mathrm{l} \mathrm{CTAB}$, $0.04 \mathrm{M} \mathrm{NaCl}$ ) and incubated at room temperature for $1 \mathrm{~h}$. After centrifugation ( $5 \mathrm{~min}, 16,000 \mathrm{~g}$ ), the supernatant was discarded and the precipitate was dissolved in $350 \mu \mathrm{l}$ of 1.2 $\mathrm{M} \mathrm{NaCl}$ and extracted with $350 \mu \mathrm{l}$ chloroform. The mixture was centrifuged $(10 \mathrm{~min}, 16,000 \mathrm{~g})$ and the upper phase was mixed with 0.6 volume parts of isopropanol. The mixture was centrifuged (10 min, 16,000g), the supernatant was discarded and the pellet was washed with $500 \mu \mathrm{l}$ of ethanol solution $(70 \% \mathrm{v} / \mathrm{v})$. After centrifugation, the supernatant was discarded carefully, the pellet was dried and the DNA was dissolved in $100 \mu \mathrm{l}$ sterile deionised water. This method was previously used for DNA extraction from seeds of soybean, wheat, barley, oats, maize and rice [13]. The DNA quality and quantity was assessed by agarose gel electrophoresis.

\subsection{PCR Analysis}

The PCR primers used in this study are shown in Table 1. The plant-specific sequences were selected based on the published data [14-15] as well as maize-specific primer pairs corresponding to invertase gene were taken from the early publications [7, 16]. In addition, new PCR primers targeting maize zein gene designed in this study, were as follows: ZEINf: 5' - ACACCACCGACCATGGCAGC-3' and ZEINr: 5'- TGGTGGCAAGTGCGCTGGAA-3'. The oligonucleotides were synthesized and purified by MWG Biotech.

Table 1. Oligonucleotide primers used in PCRs

\begin{tabular}{llll}
\hline Target & Primers & Amplicon (bp) & Reference \\
\hline Chloroplast & plant1/plant2 & $500-600$ & {$[10]$} \\
genome & IVTAS1/IVTAS2 & 226 & {$[3]$} \\
Invertase gene & IVRf/IVRr & 140 & {$[12]$} \\
Invertase gene & ZEINf/ZEINr & 102 & This study \\
Zein gene & & & \\
\hline
\end{tabular}

All PCR analyses were performed with a thermal cycler Techne TC -412. The polymerase chain reactions were carried out in a final volume of $25 \mu$ using using 1.25 U Taq DNA polymerase with standard Taq Buffer (New England BioLabs), $1.5 \mathrm{mM} \mathrm{MgCl2}, 0.2 \mathrm{mM}$ of each dNTP (Deoxynucleotide solution mix, New England BioLabs) 0.4 $\mu \mathrm{M}$ of each primer, and $1 \mu \mathrm{l}(60-70 \mathrm{ng})$ of genomic DNA. The triplex polymerase chain reactions was carried out in a final volume of $25 \mu \mathrm{l}$ using multiplex PCR lit (Qiagen), primers (0.3 $\mu \mathrm{M}$ IVTAS1/IVTAS2; $0.3 \mu \mathrm{M}$ IVRf, IVRr; 0.7 $\mu \mathrm{M}$ ZEINf/ZEINr), and $90 \mathrm{ng}$ of genomic DNA.

The PCR cycling profile for primers plant $1 /$ plant 2 was as follows: Initial single denaturation step at $95^{\circ} \mathrm{C}$ for $4 \mathrm{~min}$, followed by 35 cycles of $95^{\circ} \mathrm{C}$ for $30 \mathrm{~s}, 62^{\circ} \mathrm{C}$ for $30 \mathrm{~s}, 72^{\circ} \mathrm{C}$ for $2 \mathrm{~min}$; final extension step at $720 \mathrm{C}$ for $5 \mathrm{~min}$. The same uniplex PCR conditions were utilized for maize-specific primers IVTAS1/IVTAS2, IVRf/IVRr and ZEINf/ZEINr, such as: denaturation at $95^{\circ} \mathrm{C}$ for $3 \mathrm{~min}$, followed by 40 cycles of $95^{\circ} \mathrm{C}$ for $30 \mathrm{~s}, 63^{\circ} \mathrm{C}$ for $30 \mathrm{~s}, 72^{\circ} \mathrm{C}$ for $35 \mathrm{~s}$; final extension step at $720 \mathrm{C}$ for $5 \mathrm{~min}$. The amplification profile for triplex PCR was as follows: denaturation for $15 \mathrm{~min}$ at $95^{\circ} \mathrm{C}, 40$ cycles consisting of denaturation at $95^{\circ} \mathrm{C}$ for $30 \mathrm{~s}$, annealing at $65^{\circ} \mathrm{C}$ for $30 \mathrm{~s}$, elongation at $72^{\circ} \mathrm{C}$ for $30 \mathrm{~s}$; final extension step for $7 \mathrm{~min}$ at $72^{\circ} \mathrm{C}$.

\subsection{Agarose Gel Electrophoresis}

Both the genomic DNAs and PCR products were analyzed by agarose gel electrophoresis using 1.0 and $2.0 \%$ of SeaKem LE agarose (Cambrex) gels for genomic and amplified DNA, respectively. Electrophoresis was run in the 1x TBE (Tris-Borate EDTA) buffer containing $1 \mu \mathrm{g} / \mathrm{ml}$ of Ethidium Bromide (EtBr). After electrophoresis the DNA bands were visualized and photographed by Digital still camera (DSC-S600, Sony).

\section{Results and Discussion}

PCR-based analysis of foods applied in this study consisted of the following steps: sample preparation, DNA extraction, assessment of DNA quantity and integrity by gel electrophoresis, amplification of the target sequences by PCR, and assessment of PCR products by agarose gel electrophoresis.

\subsection{Evaluation of Genomic DNAs by Gel Electrophoresis}

The electrophoretic gel images of genomic DNAs extracted from the foodstuffs are shown in Fig.1a. Corn flour yielded a visible whole DNA (Fig.1a, lane 1) as was previously reported by us [13]. However degradation was found in DNAs extracted from all other foodstuffs (Fig.1a, lanes 2-4) while no visible band was exhibited for corn flakes (Fig.1a, lane 3). Comparison of the results obtained revealed that corn flour gave high-molecular-weight DNA with highest integrity and corn flakes gave the most degraded DNA. These results suggested that corn flour was the least processed, while corn flakes were the most highly processed among the foodstuffs investigated in this study.

\subsection{Evaluation of DNA Amplifiability}

In order to evaluate DNA amplifiability, all of the samples analyzed were subjected to PCR amplification with plant-specific primer pair plant1/plant2, targeting conserved sequences of chloroplast genome [14]. Fig. 1b shows gel electrophoresis of amplification products produced by plant-specific PCR. Corn flour and snacks generated one main amplicon approximately 500 bp in size (Fig. 1b, lanes 1 and 4) as was previously demonstrated by us for maize flour [13]. However corn chips gave the main 500 bp amplicon and two additional weak bands approximately 370 
bp and 150 bp in size (Fig.1b, line 2). One 370 bp DNA band with less intensity was observed for corn flakes while no visible main $500 \mathrm{bp}$ amplicon was identified for this sample

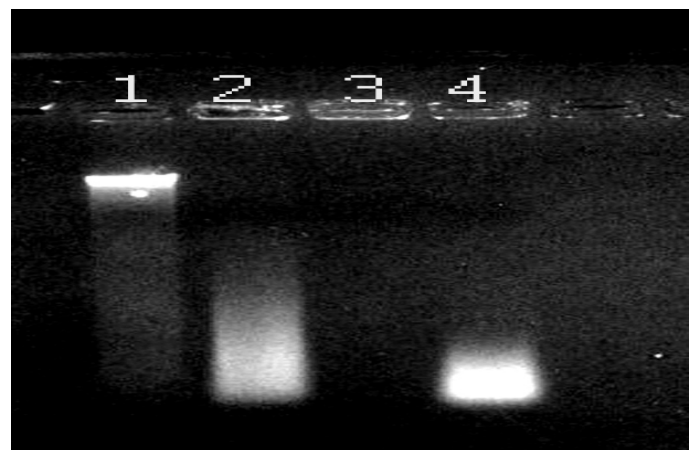

(a)

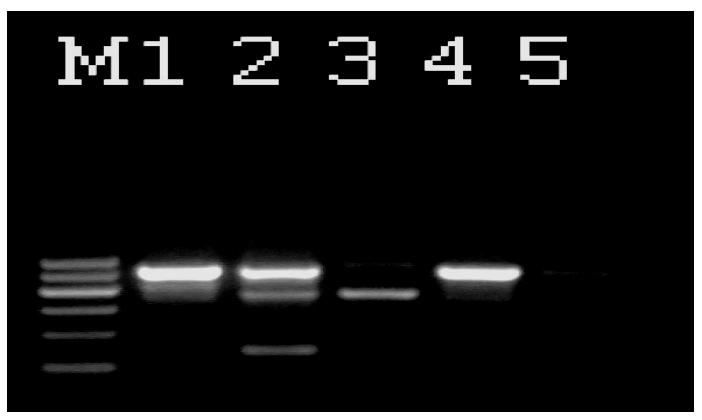

(b)

Figure 1. (a) Genomic DNAs extracted from corn food samples (b) Plant-specific PCR using primers plant1/plant2 for corn foodstuffs. Samples: lane 1. flour, lane 2. chips, lane 3. flakes, lane 4. snacks, lane 5. water. M. GelPilot 100 bp ladder (Qiagen): 100 bp, 200 bp, 300 bp, 400 bp, $500 \mathrm{bp}, 600 \mathrm{bp}$.

(Fig.1b, line 3). These findings indicate that $500 \mathrm{bp}$ fragments of genomic DNAs from corn flour and snacks are not degraded however the same fragments from chips are partially degraded while fragments of corn flakes are almost wholly degraded. These outcomes correspond to the results of genomic DNA degradation for these foodstuffs (Fig. 1a).

\subsection{Comparison of PCR Methods for Corn Detection in Foods}

Three pairs of oligonucleotide primers were applied for corn detection in this study (table 1). Two of them are specific to maize invertase gene and were developed by Elhers et al. [7] and Kutateladze et al. [16]. The PCR primers ZEINf and ZEINr specific to zein gene were designed in this study. Gel electrophoresis of the PCR products of chips and snacks (Fig. 2a, lanes 1-3, 11-13) showed that one amplicon in size of $226 \mathrm{bp}, 140 \mathrm{bp}$ and $102 \mathrm{bp}$ was obtained for the primer pairs IVTAS1/IVTAS2, IVRf/IVRr and ZEINf/ZEINr respectively, as was expected. These results correspond to the outcomes previously reported about suitability of the primers corresponding to invertase gene for reliable identification of corn in some foods [16] and feedstuffs [9]. However one $226 \mathrm{bp}$ band with less intensity was generated with primer pair IVTAS1/IVTAS2 for corn flakes (Fig.2a, lane 6) while no visible bands was detected for primer pairs IVRf/IVRr and ZEINf/ZEINr (Fig.2a, lines $4,5)$. No amplification product was observed for water control (Fig. 2a, lane 10). Therefore, analysis of processed foods by uniplex PCRs using the abovementioned maize-specific primers revealed that all of the primer pairs are useful for detection of corn in less and middle processed products, such as flour, chips and snacks. However these primers failed in analysis of highly processed corn flakes while PCR with IVTAS1/ IVTAS2 identified corn with less precision.

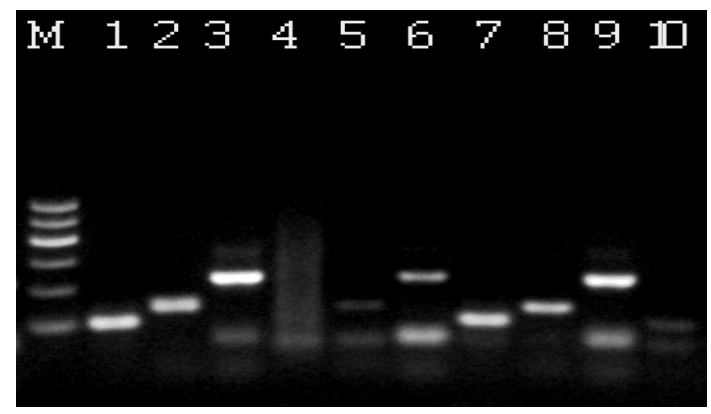

(a)

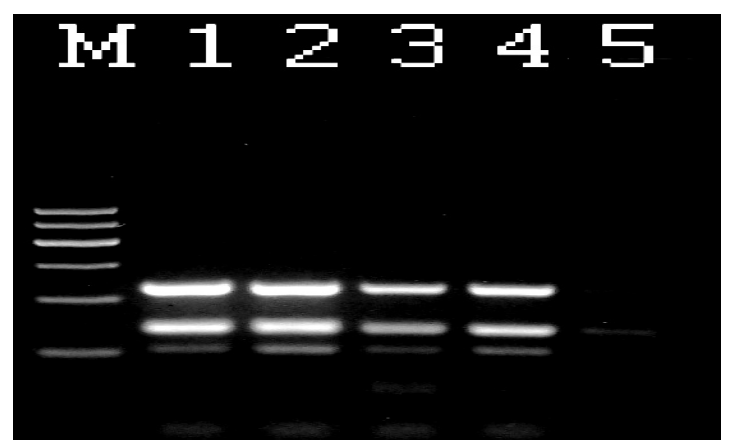

(b)

Figure 2. (a) Corn-specific uniplex PCRs using primers: ZEINf/ZEINr (lanes 1, 4, 7, 10), IVRf/IVRr (lanes 2, 5, 8), IVTAS1/IVTAS2 (lanes 3, 6, 9). Samples: lanes 1-3. chips, lanes 4-6. flakes, lanes 7-9. snacks. lane 10. water. (b) Triplex PCR with primers IVTAS1/IVTAS2, IVRf/IVRr and ZEINf/ZEINr. Samples: lane 1. flour, lane 2. chips, lane 3. flakes, lane 4. snacks, lane 5. water. M. GelPilot 100 bp ladder (Qiagen): 100 bp, 200 bp, $300 \mathrm{bp}, 400 \mathrm{bp}, 500 \mathrm{bp}, 600 \mathrm{bp}$.

Subsequently multiplex approach was applied to improve accuracy of the corn detection in the highly processed foods. Multiplex PCR allowing simultaneous detection of several targets in one reaction enables reliable, rapid and cheap analysis of foods [10-12, 16]. In this study new triplex PCR was developed using three primer pairs such as IVTAS1/IVTAS2, IVRf/IVRr and ZEINf/ZEINr that allows simultaneous identification of two $226 \mathrm{bp}$ and $140 \mathrm{bp}$ fragments of corn invertase gene and one $102 \mathrm{bp}$ fragment of zein gene in one reaction. Fig. $2 b$ represents gel electrophoresis of the triplex PCR products for corn foodstuffs investigated. Three expected amplicons were obtained for each sample (Fig. 2b, lanes 1-4). Evidently, corn flakes generated more intense bands (Fig. 2b, lane 3) than bands obtained by uniplex PCR (Fig. 2a, lanes 4-6). No 
PCR fragment was seen for water control (Fig. 2b, lane 5). The results obtained indicate high specificity and accuracy of the developed triplex PCR system for detection of corn ingredients and additives in foodstuffs.

\section{Conclusion}

In this study, it was seen that the new designed primers targeting zein gene as well as primers specific to invertase gene allow precise and specific detection of corn in little and middle processed foods. However it is concluded that triplex PCR method developed in this study is more advantageous way for fast and reliable identification of corn ingredients and additives in highly processed foods.

\section{Acknowledgements}

This study has been fulfilled by the financial support of the Shota Rustaveli National Science Foundation (Grant \# 30/37).

\section{References}

[1] LJ. Stevens, T. Kuczek, JR. Burgess, E. Hurt, and LE. Arnold, "Dietary sensitivities and ADHD symptoms: thirty-five years of research", vol. 50, 2011, pp. 279-93.

[2] JA. Bernstein, II. Bernstein, L. Bucchini, LR. Goldman, RG. Hamilton, S. Lehrer, C. Rubin, and HA. Sampson, "Clinical and laboratory investigation of allergy to genetically modified foods", Environ Health Perspect., vol. 111, 2003, pp. 114-21.

[3] C. James, "Global status of commercialized biotech/GM crops: 2010", Briefs of the International Service for the Acquisition of Agri-Biotech Applications (ISAAA), Brief 42, pp. 1-9.

[4] M. Onishi, T. Matsuoka, T. Kodama, K. Kashiwaba, S. Futo, H. Akiyama, T. Maitani, S. Furui, T. Oguchi, and A. Hino, "Development of a multiplex polymerase chain reaction method for simultaneous detection of eight events of genetically modified maize", Journal of Agricultural and Food Chemistry, vol.53, 2005, pp. 9713-9721.

[5] E. Anklam, F. Gadani, P. Heinze, H. Pijnenburg, and G. Van den Eede, "Analytical methods for detection and determination of genetically modified organisms (GMO's) in agricultural crops and plant-derived food products", European Food Research and Technology, vol. 214, 2002, pp. $3-26$.

[6] D. James, DA-M. Schmidt, E. Wall, M. Green, and S. Masri,
"Reliable detection and identification of genetically modified maize, soybean and canola by multiplex PCR analysis", Journal of Agricultural and Food Chemistry, vol. 51, 2003, pp. 5839-5834.

[7] B. Ehlers, E. Strauch, M. Goltz, D. Kubsch, H. Wagner, H. Maidhof, J. Bendiek, B. Appel, and H-J. Buhk, "Nachweis gentechnischer Veränderungen in Mais mittels PCR", Bundesgesundheitsblatt-Gesundheitsforschung Gesundheitsschutz, vol. 4, 1997, pp. 118-120.

[8] M. Hernández, T. Esteve, S. Prat, and M. Pla, "Development of real-time PCR systems based on $\mathrm{SYBR}^{\circledR}$ Green I, Amplifluor $^{\mathrm{TM}}$. and $\mathrm{TaqMan}^{\circledR}$ technologies for specific quantitative detection of the transgenic maize event GA21", Journal of Cereal Science, vol. 39, 2004, pp. 99-107.

[9] S. Tavoletti, L. Iommarini, and M. Pasquini, "A DNA method for qualitative identification of plant raw materials in feedstuff', European Food Research and Technology, vol. 229, 2009, pp. 475-484.

[10] A. Germini, A. Zanetti, C. Salati, S. Rossi, C. Forre, S. Schmid, and R. Marchelli, "Develoment of a seven-target multiplex PCR for the simultaneous detection of transgenic soybean and maize in feeds and foods", Journal of Agricultural and Food Chemistry, vol. 52, 2004, pp. 3275-3280.

[11] M. C. Samson, M. Gulli, and N. Marmiroli, "Multiple real-time PCR assays for simultaneous detection of maize MON810 and GA21 in food samples", Food Control, vol. 30, 2013, pp. 518-525.

[12] M. Onishi, T. Matsuoka, T. Kodama, K. Kashiwaba, S. Futo, H. Akiyama, T. Maitani, S. Furui, T. Oguchi, and A. Hino, "Development of a multiplex polymerase chain reaction method for simultaneous detection of eight events of genetically modified maize", Journal of Agricultural and Food Chemistry, vol. 53, 2005, pp. 9713-9721.

[13] N. Datukishvili, I. Gabriadze, T. Kutateladze, M. Karseladze, and B. Vishnepolsky, "Comparative evaluation of DNA extraction methods for food crops", International Journal of Food Science and Technology, vol. 45, 2010, pp. 1316-1320.

[14] P. Taberlet, L. Gielly, G. Pautou, and J. Bouvet, "Universal primers for amplification of three non-coding regions of chloroplast DNA", Plant Molecular Biology, vol. 17, 1991, pp. 1105-1109.

[15] K. Pietsch, H. U. Waiblinger, P. Brodmann, and A. Wurz, „Screeningverfahren zur Identi®zierung gentechnisch veraenderter pflanzlicher Lebensmittel'“, Deutsche Lebensmittel-Rundschau, vol. 93, 1997, pp. 35-38.

[16] T. Kutateladze, I. Gabriadze, B. Vishnepolsky, M. Karseladze, and N. Datukishvili, "Development of triplex PCR for simultaneous detection of maize, wheat and soybean", Food Control, vol. 34, 2013, pp. 698-702. 